\title{
Analysis of the Level of Patient Satisfaction on Out- Patient Installation Based on Hospital Minimum Service Standard in Dr. Pirngadi Regional Public Hospital Medan City
}

\author{
Chrisna Ratnawati Pardede ${ }^{1}$, Harmein Nasution², Linda Trimurni Maas ${ }^{2}$ \\ ${ }^{1,2}$ Master of Management Study Program on Postgraduate School of University of Sumatera Utara
}

Corresponding Author: Chrisna Ratnawati Pardede

\begin{abstract}
Minimum service standard is intended to provide guidelines for the regions in implementing the planning implementation and control as well as supervision and accountability for the implementation of hospital minimum service standards. Hospital minimum service standard includes types of service indicators and standards for achieving hospital service performance, one of which is out-patient services. According to The Decree of the Minister of Health of the Republic of Indonesia No. 560/Menkes/SK/IV/2003, that out-patient services are patient services for observation, diagnosis, treatment, medical rehabilitation and other health services without being hospitalize. The research is conducted on 100 out-patient respondents at the Dr. Pirngadi Regional Public Hospital in Medan City. This research used quantitative descriptive method, the analysis carried out using statistical tests of the data collected, using the help of the SPSS programme. The result of the research found that patients are satisfied with the hospital's minimum service standard with the dimensions of service quality summarized by the hospital service standard indicators based on government regulations.
\end{abstract}

Keywords: Service Standard, Patient Satisfaction

\section{BACKGROUND}

Hospital as a health facility that provides health services to the community has a very strategic role in accelerating the improvement of community health status. Therefore hospitals are required to provide quality services in accordance with established standards and can reach all levels of society. One of the things that the community wants is government services in the health sector where currently economic disparities mean that marginalized people cannot go to hospital due to economic limitations. Currently the government has issued many health programs, for example: Health Insurance (ASKES), Public Health Insurance (JAMKESMAS) which has now been changed to the Badan Penyelenggara Jaminan Sosial (BPJS) Kesehatan.

The problem that is often faced by hospitals is that the hospital has not been able to provide something that service users really expect. The main factor is because the services provided are of low quality so that they cannot produce the services that patients expect. The hospital is an organization that sells services, so quality service is a requirement that must be met. If the patient does not find satisfaction with the quality of service provided, the patient tends to make the decision not to re-visit the hospital. This also happened to the Regional Public Hospital Dr. Pirngadi in Medan City, although considered to be quite good in providing services, compared to several other hospitals in Medan City, in reality there are still deficiencies in the service process. This is evidenced by the many complaints and complaints from the public, 
both through social media, criticism from experts in various articles concerning service mechanisms that are still unsatisfactory for patients and their families. One of the problems that is often encountered by a hospital is that it comes from outpatient installations.

Research and Development Division of Dr. Pirngadi Regional Public Hospital of Medan City stated that there was a significant decrease in the number of patients. This is indicated by the level of patient satisfaction that has not been met. Several things caused the dissatisfaction to occur, such as the physical hospital, rooms and equipment. Likewise, other causes related to services such as friendliness of officers and medical teams. The things that are felt are the talk among the public, coupled with the problem of drugs that are not available. (Research and Development, Dr. Pirngadi Regional Public Hospital Medan City, 2019). Even though Dr. Pirngadi Regional Public Hospital has used minimum service standards based on the Decree of the Minister of Health of the Republic of Indonesia Number: 129 / Menkes / SK / II / 2008 concerning Hospital Minimum Service Standards. This minimum service standard is intended to provide guidance for regions in implementing implementation planning and control as well as supervision and accountability for the implementation of hospital minimum service standards. This minimum service standard aims to equalize understanding of operational definitions, performance indicators, measures or units of reference and national targets.

Table 1. Number of Outpatients in Dr. Pirngadi Regional Public Hospital of Medan City 2014 - 2019

\begin{tabular}{|l|l|}
\hline Year & Number of Patients \\
\hline 2014 & 201.572 \\
\hline 2015 & 196.072 \\
\hline 2016 & 332.342 \\
\hline 2017 & 161.351 \\
\hline 2018 & 134.100 \\
\hline 2019 & 97.126 \\
\hline
\end{tabular}

\section{Minimum Outpatient Service Standards}

Based on the results of the decision of the Minister of Health of the Republic of Indonesia No. 560 / Menkes / SK / IV / 2003 states that outpatient services are patient services for observation, diagnosis, treatment, medical rehabilitation and other health services without staying in the hospital. Outpatient first level is individual health service that is non-specialized in nature which is carried out at first level health facilities for the purposes of observation, diagnosis, treatment, and / or other health services.

Table 2 Minimum Hospital Outpatient Service Standards

\begin{tabular}{|c|c|c|c|}
\hline No. & $\begin{array}{ll}\begin{array}{l}\text { Kind } \\
\text { service }\end{array} & \text { of } \\
\end{array}$ & Indicators & Standart \\
\hline \multirow{7}{*}{1} & \multirow{7}{*}{ Outpatient } & Doctor providing services at the Specialist Polyclinic & $100 \%$ Medical specialist \\
\hline & & Availability of services & $\begin{array}{l}\text { Children's clinic } \\
\text { Internal medicine clinic } \\
\text { Midwifery clinic } \\
\text { Surgical clinic }\end{array}$ \\
\hline & & Availability of services in mental hospitals & $\begin{array}{l}\text { Teen } \\
\text { DRUGS } \\
\text { Psychotic Disorders } \\
\text { Neurotic Disorders } \\
\text { Mental Retardation } \\
\text { Mental Organic } \\
\text { Elderly }\end{array}$ \\
\hline & & Service opening hours & $\begin{array}{l}08.00 \text { s/d } 13.00 \text { Every weekday except Friday : } \\
08.00-11.00\end{array}$ \\
\hline & & Outpatient waiting time & $\leq 60$ menit \\
\hline & & Customer satisfaction & $\geq 90 \%$ \\
\hline & & $\begin{array}{l}\text { Diagnosis of TB through TB microscopy } \\
\text { Implementation of TB recording and reporting activities at } \\
\text { the hospital }\end{array}$ & $\begin{array}{l}\text { a. } \geq 60 \% \\
\text { b. } \leq 60 \%\end{array}$ \\
\hline
\end{tabular}




\section{Customer Satisfaction}

The definition of patient satisfaction according to Kotler is the feeling of pleasure or disappointment of someone who comes after comparing their perceptions or impressions of the performance or results of a product and their expectations (Nursalam, 2011). Patient satisfaction is a health service outcome. Thus patient satisfaction is one of the goals of improving the quality of health services. Patient satisfaction is a level of patient feeling that arises as a result of the performance of health services that he gets after the patient compares it with what he expects (Pohan, 2007).

\section{Factors Affecting Patient Satisfaction}

According to Sangadji and Sopiah (2013), the factors that affect patient satisfaction include:

1. Characteristics of the patient. The determinants of the level of patients or consumers by the characteristics of the patient which are the characteristics of a person or the uniqueness of a person that distinguishes one person from another. These characteristics are name, age, gender, educational background, ethnicity, religion, occupation and others.

2. Physical means. In the form of visible physical evidence which includes buildings, equipment, employee uniforms and means of communication.

3. Guarantee. The nurse's knowledge, abilities, politeness, and trustworthiness.

4. Caring. Ease of building good communication between employees and clients, personal attention, and understanding customer needs.

5. Reliability. Ability to provide promised services quickly, precisely, accurately and satisfactorily.

Satisfaction of health service users can be concluded as the difference between the performance of health service institutions and patient expectations (Muninjaya, 2013). From this explanation, customer satisfaction can be formulated as follows:
Satisfaction $=\mathrm{f}($ performance-expectation $)$

From this formula, three possibilities are generated, namely:

1. Performance < Expectation, if the performance of health services is worse than what users expect, the performance of health services will be considered bad by users, because it is not in accordance with user expectations before receiving health services. As a result, service users are not satisfied with the services received.

2. Performance $=$ Expectation, if the performance of health services is the same as the expectations of its users, users of health services will receive good service performance. Services received are according to what users expect. As a result, service users are satisfied with the services received.

3. Performance > Expectation, when the performance of health services is higher than what users expect, users will receive services that exceed their expectations. As a result, the customers were very satisfied with the health services received.

\section{Service quality}

According to Tjiptono (2007)

Service Quality is the level of excellence expected and control over this level of excellence to meet customer desires. Service Quality is the difference between the expectations and the reality of the customers for the services they receive. Service Quality can be identified by comparing customer perceptions of the service they actually receive with the actual service they expect. Service quality has five basic dimensions. Expected services and perceived services have the same dimensions. This dimension is assessed when customers are asked to state the expected and perceived services they receive. The dimensions of service quality are: 


\section{Tangibles (direct evidence)}

The service process carried out by the service provider to the customer must be visible or physically visible regarding the working mechanisms of the various facilities used, equipment, performance of officers, and so on.

\section{Reliability}

Service providers must be able to fulfill or carry out services reliably and accurately, both regarding the timeliness of service, the speed of the officers in serving customers, and the simplicity of service procedures.

\section{Responsiveness}

Includes how the service provider responds to customer complaints regarding unsatisfactory or unsatisfactory service, the service provider's actions towards customer complaints, and how the attitude of the officers in responding to customers who submit complaints.

\section{Assurance}

Includes the ability and knowledge of officers in providing services, friendliness and courtesy of officers in providing services, and service security.

\section{Empathy}

Includes patience and honesty of officers in providing services, fair attitude of officers in serving each customer, a firm but attentive attitude towards consumers, making it easier to make good communication relationships and understand the needs of customers.

\section{Conceptual framework}

Patient satisfaction is a health service outcome. Thus patient satisfaction is one of the goals of improving the quality of health services. In an effort to increase patient satisfaction, this can be seen from the service standards that apply in the hospital where currently Dr. Pirngadi Regional Public Hospital of Medan City measures the achievement of minimum service standards for outpatient installations using the Decree of the Minister of Health of the Republic of Indonesia No. 129 / Menkes / SK / II / 2008.

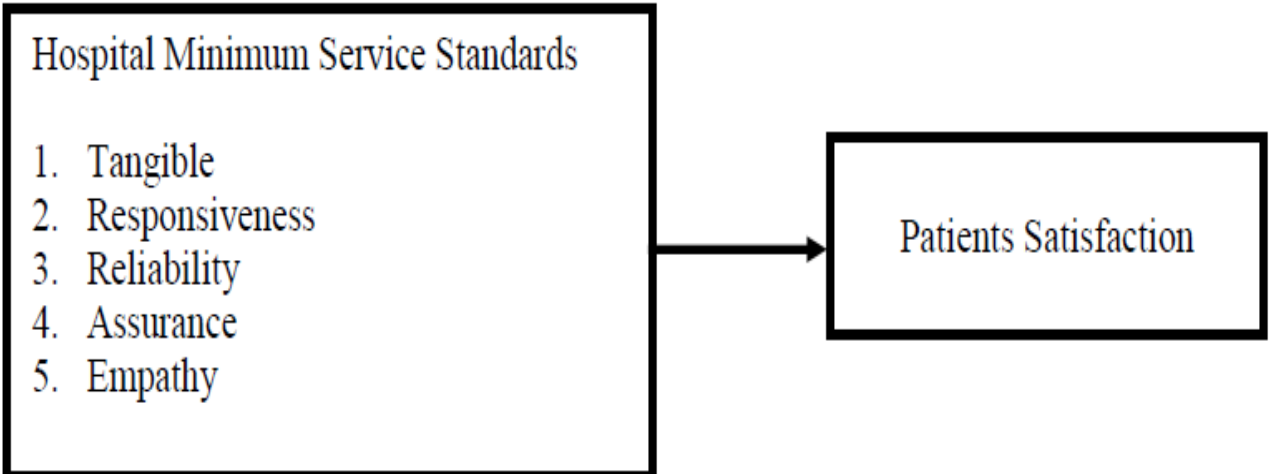

Figure 1 Conceptual Framework

\section{RESEARCH METHODS}

This research is a descriptive study with a quantitative approach. This descriptive study aims to analyze the level of patient satisfaction based on the minimum service standards Dr. Pirngadi Regional Public Hospital Medan City. The population of this study was 97,126 outpatients in 2019 (Medical Record of Dr. Pirngadi General Hospital, 2020). Determination of the number of samples in this study using the Slovin formula with a sample size of 100 people. Sampling using Accidental Sampling technique. The data collection technique used questionnaires and interviews with related parties, in this case the research and development, medical records and outpatients at Dr. Pirngadi Regional Public Hospital Medan City. Interviews were conducted based on a prepared list of questions. 
RESULT

Tangible

In this dimension, which is included in the quite satisfying category, namely the comfort of Dr. Pirngadi Regional Public Hospital Medan with a mean value of 3.03. This means that the service for the waiting room is good and in accordance with patient expectations. This of course needs to be maintained and even improved. Likewise, the cleanliness of Dr. Pirngadi Regional Public Hospital Medan is included in the satisfactory category with a mean value of 3.51. Which means the cleanliness of the Outpatient Clinic is always kept clean.

Overall, in this dimension the average satisfaction rating is 3.27 , which means that it is in the medium or quite satisfactory category. It can be said that the patient is satisfied with the services provided by Dr. Pirngadi Regional Public Hospital Medan. Patients are satisfied with hospital services with the availability of supporting facilities and infrastructure.

\section{Reability}

Overall, in this dimension, the average value of the satisfaction level is 3.718 which means it is in the high or satisfying category. It can be said that the patient is satisfied with the services provided by Dr. Pirngadi Regional Public Hospital Medan. Patients feel satisfied with hospital services as seen from the doctor's responsiveness, doctor's skills and expertise, waiting time and also the patient's treatment schedule.

\section{Responsiveness}

In this dimension, all statements are in the high category which means satisfying. Namely a statement regarding doctors who are responsive to patient complaints, doctors who correctly diagnose patients, nurses who are alert when sudden events occur and service opening hours are always on time. Overall, in this dimension the average satisfaction rating is 3.61 , which means it is in the high or satisfactory category. It can be said that the patient is satisfied with the services provided by Dr. Pirngadi Regional Public Hospital Medan.

\section{Assurance}

In this dimension, all statements are in the high category which means satisfying. Namely a statement regarding the determination of the diagnosis by the doctor, the solution to the diagnosis, the skills of the nurse and also the initial registration officer. Overall, in this dimension the average satisfaction rating is 3.71 which means it is in the high or satisfying category. It can be said that the patient is satisfied with the services provided by Dr. Pirngadi Regional Public Hospital of Medan City.

\section{Empathy}

Overall, in this dimension, the average satisfaction rating is 3.56 , which means it is in the high or satisfying category. It can be said that the patient is satisfied with the services provided by Dr. Pirngadi Regional Public Hospital of Medan City.

\section{CONCLUSION}

Based on the results of a survey of 100 outpatients, it can be concluded that the patient is satisfied with the minimum hospital service standards with the dimensions of service quality which are summarized by indicators of hospital service standards based on government regulations, namely doctors providing services, service availability, services time and waiting time. in an outpatient installation at Dr. Pirngadi Regional Public Hospital of Medan City. Tangible dimension (tangible) which is still in the medium category, which means that the patient feels quite satisfied with the patient waiting room services and outpatient clinic in Dr. Pirngadi Regional Public Hospital of Medan City 


\section{REFERENCES}

1. Arikunto, S. 2010. Prosedur Penelitian Suatu Pendekatan Praktik. Jakarta: PT.Rineka Cipta.

2. Awinda, D. 2004. Tingkat Kepuasan Pasien Perusahaan dan Pasien Pribadi terhadap Mutu Pelayanan Ruang Rawat Inap Kelas III RS. Permata Bunda Medan. Medan

3. Departemen Kesehatan RI, 2010, Peraturan Menteri Kesehatan Republik Indonesia Nomor 340/MENKES/PER/III/2010, tentang Klasifikasi Rumah Sakit: Jakarta.

4. Ghozali, Imam. 2006. Aplikasi Analisis Multivariate dengan Program SPSS (Edisi Ke 4). Semarang: Badan Penerbit Universitas Diponegoro.

5. Keputusan Menteri Kesehatan Republik Indonesia No. 560/Menkes/SK/IV/2003 tentang Pola Tarif Perjan Rumah Sakit

6. Keputusan Menteri Kesehatan Republik Indonesia No. 129/Menkes/SK/II/2008 tentang Standar Pelayanan Minimal Rumah Sakit

7. Keputusan Menteri Kesehatan Republik Indonesia No. 340/Menkes/Per/III/2010 tentang Klasifikasi Rumah Sakit

8. Keputusan Menteri Pendayagunaan Aparatur Negara No. KEP/25/M.PAN/2/2004 tentang Pedoman Umum Penyusunan Indeks Kepuasan Masyarakat Unit Pelayanan Instansi Pemerintah

9. Lestari, Yuni. 2017. Analisis Tingkat Kepuasan Pasien Rawat Jalan. Semarang

10. Lupiyoadi, Hamdani. 2006. Manajemen Pemasaran Jasa, Edisi Kedua. Jakarta: Penerbit Salemba Empat.

11. Menteri Kesehatan Republik Indonesia Nomor : 129/Menkes/SK/II/2008 tentang Standar Pelayaan Minimal Rumah Sakit

12. Munijaya, Gde AA. 2013. Manajemen Mutu Pelayanan Kesehatan. Jakarta: EGC

13. Mustika, Dewi . 2019. Kepuasan Pasien terhadap Layanan Rawat Inap RSUD Jagakarsa Tahun 2017/2018. Jakarta

14. Nursalam. 2011. Manajemen Mutu Pelayanan Kesehatan. Jakarta : EGC.

15. Nursalam. 2011. Manajemen Keperawatan Edisi 3. Jakarta: Salemba Medika
16. Peraturan Pemerintah Republik Indonesia No. 65 tahun 2005 tentang Pedoman Penyusunan dan Penerapan Standar Minimal

17. Peraturan Pemerintah Republik Indonesia No. 58 tahun 2005 tentang Pengelolaan Keuangan Daerah

18. Permenkes No. 71 tahun 2013 tentang Pelayanan Kesehatan pada Jaminan Kesehatan Nasional

19. Pohan, Imbolo. 2007. Jaminan mutu layanan kesehatan. Jakarta: Penerbit Buku Kedokteran EGC.

20. Pohan, Imbolo. 2007. Jaminan Mutu Layanan Kesehatan: Dasar-Dasar Pengertian dan Penerapan. Jakarta: EGC

21. Purnomo, Hari. 2002. Pengukuran Kualitas Pelanggan. Yogyakarta: Penerbit Graha Ilmu.

22. Sangadji, E.M., dan Sopiah. 2013. Perilaku Konsumen: Pendekatan Praktis Disertasi: Himpunan Jurnal Penelitian. Yogyakarta: Penerbit Andi

23. Siagian, Dergibson, Sugiarto. 2006. Metode statistika Untuk Bisnis dan Ekonomi. Jakarta: PT. Gramedia Pustaka Utama.

24. Simamora, Bilson. 2002. Panduan Riset Perilaku Konsumen. Surabaya: Pustaka Utama

25. Sugiyono. 2016. Metode Penelitian Kombinasi (Mix Methods). Bandung : Alfabeta.

26. Sugiyono. 2009. Metode Penelitian Kuantitatif, Kualitatif dan R\&D. Bandung: Alfabeta.

27. Suh, Y. I., Ahn, T., \&Pedersen, P. M. 2013. Examining the EEffects of Team Identification, E-service Ouality (e-SQ) and Satisfaction on Intention to Revisit Sports Websites: International Journal of Sports Marketing and Sponsorship

28. Tjiptono. 2001. Manajemen Pemasaran dan Analisa Perilaku Konsumen. Yogyakarta: BPFE.

29. Tjiptono, Fandy dan G. Chandra. 2005. Service, Quality, \& Satisfaction. Yogyakarta: Penerbit Andi

30. Tjiptono, Fandy. 2006. Manajemen Pelayanan Jasa, Yogyakarta: Penerbit Andi. 
Chrisna Ratnawati Pardede et.al. Analysis of the level of patient satisfaction on out-patient installation based on hospital minimum service standard in Dr. Pirngadi Regional Public Hospital Medan City.

31. Tjiptono, Fandy. 2007. Strategi Pemasaran. Edisi Pertama. Yogyakarta: Andi Ofset.

32. Tiyas dan Achmad. 2011. Analisis Tingkat Kepuasan Pasien Rawat Jalan Terhadap Kualitas Pelayanan Instalasi Farmasi RSUD Setjonegoro Wonosobo. Jurnal Manajemen dan Pelayanan Farmasi. Vol.1, No. 2 : 119-125

33. Undang-Undang Republik Indonesia No. 36 tahun 2009 tentang Kesehatan
34. Undang-Undang Republik Indonesia No. 44 Tahun 2009 tentang Rumah Sakit

How to cite this article: Pardede CR, Nasution $\mathrm{H}$, Maas LT. Analysis of the level of patient satisfaction on out-patient installation based on hospital minimum service standard in Dr. Pirngadi Regional Public Hospital Medan City. International Journal of Research and Review. 2021; 8(2): 54-60. 